\title{
Towards Supported Decision-Making: Article 12 of the Convention on the Rights of Persons with Disabilities and Guardianship Law Reform
}

\author{
Bruce Alston*
}

\begin{abstract}
In 2014, a set of National Decision-Making Principles (the Principles) was recommended by the Australian Law Reform Commission as a legal policy guide for reform of Commonwealth, State and Territory laws. The Principles were aimed to encourage supported decision-making; make the appointment of representatives only a last resort; and to ensure that the will, preferences and rights of individuals direct decisions affecting their lives. This article discusses the sources of the Principles and their relationship to Art 12 of the Convention on the Rights of Persons with Disabilities. The article then examines the steps that are needed to give the Principles full effect in Australian laws to regulate decision-making by individuals who require support. A major focus in implementing a paradigm shift towards supported decision-making is reform of State and Territory guardianship and administration laws. The article examines how guardianship laws should be reformed consistently with the Principles - to ensure that guardianship is invoked only as a last resort and after considering the availability of support to assist people in decision-making. Further, guardianship should be as confined in scope and duration as is reasonably possible; subject to accessible mechanisms for review; and decision-making should respect the will, preferences and rights of the individual. At Commonwealth level, the National Disability Insurance Scheme legislation incorporates some elements of supported decision-making. However, these should also be augmented by providing legal recognition for supporters, and associated safeguards. The author suggests that the Principles can be a catalyst for facilitating important law reform over following decades. The article examines how the Principles may be used by communities, policy-makers and governments to promote world-leading legal changes to ensure that individuals with disability have an equal right to make decisions for themselves.
\end{abstract}

\section{INTRODUCTION}

In 2014, a set of National Decision-Making Principles was recommended by the Australian Law Reform Commission ${ }^{1}$ as a legal policy guide for reform of Commonwealth, State and Territory laws that regulate

* The author acknowledges the valuable assistance of Nishadee Perera. While this article draws on the work of the Australian Law Reform Commission, the views expressed in it are those of the author and do not reflect the official opinion of the Commission. 
decision-making by individuals who require support. This article discusses the sources of the National Principles and their relationship to Art 12 of the Convention on the Rights of Persons with Disabilities (CRPD). ${ }^{2}$ It then examines the steps that are needed to give the Principles full effect in Australian laws. This new decision-making model calls for the provision of whatever support is necessary to ensure that people with disabilities are able to exercise legal rights on an equal basis with others, and to address discriminatory attitudes and barriers.

A major focus in implementing the 'paradigm shift' towards supported decision-making is reform of State and Territory guardianship and administration laws, ${ }^{3}$ including by developing alternatives. This article discusses how guardianship laws should be reformed consistently with the Principles - to ensure that guardianship is invoked only as a last resort and after considering the availability of support to assist people in decision-making. Further, guardianship should be as confined in scope and duration as is reasonably possible; subject to accessible mechanisms for review; and decision-making should respect the will, preferences and rights of the individual.

While Australia has been a past leader in progressive guardianship law and practice, ${ }^{4}$ this article argues that current guardianship laws do not comply with Art 12, notwithstanding the Australian Government's 2007 Interpretative Declaration that the CRPD 'allows for fully supported or substituted decision-making arrangements, which provide for decisions to be made on behalf of a person' ${ }^{5}$

The CRPD, as elaborated in the National Principles, should be a catalyst for important law reform over following decades. There is significant momentum towards guardianship and related law reform in a number of Australian jurisdictions. However, despite calls for more uniformity between States and Territories, there are challenges to comprehensive reform. Proposals for the complete abolition of guardianship or other forms of representative decision-making law should not be allowed to act as a barrier to reform. The author argues that 'the perfect should not be the enemy of the good', including relatively simple legislative reform to introduce the 'will, preferences and rights' concept into guardianship laws as applied to decision-making with or for adults.

$1 \quad$ Australian Law Reform Commission (ALRC), Equality, Capacity and Disability in Commonwealth Laws, Report 124 (2014) (National Principles).

2 Convention on the Rights of Persons with Disabilities, opened for signature 30 March 2007, 2515 UNTS 3 (entered into force 3 May 2008) Art 12 (CPRD).

3 Hereafter, for brevity, 'guardianship'.

4 Terry Carney, 'Supported Decision-Making for People with Cognitive Impairments: An Australian Perspective?' (2015) 4 Laws 37, 40.

5 Convention on the Rights of Persons with Disabilities: Declarations and Reservations (Australia), opened for signature 30 March 2007, 2515 UNTS 3 (entered into force 3 May 2008) (CRPD: Declarations and Reservations). 


\section{Article 12 of the CRPD}

Article 12 of the $\mathrm{CRPD}^{6}$ on 'equality recognition before the law' has been said to have brought about a 'paradigm shift' in legal understandings of disability and the appropriate treatment of persons with disability. ${ }^{7}$ This paradigm shift can be summarised as demanding full recognition that people with disabilities always be recognised as persons before the law and have the right to make choices for themselves. This requires an ongoing emphasis on the autonomy and independence of persons with disability who may require support in making decisions so that their will and preferences drive decisions, and not paternalistic 'best interests' considerations.

The most authoritative interpretation of Art 12 is that it requires states parties to abolish substitute decision-making regimes, such as guardianship and mental health laws that permit forced treatment, in order to ensure that full legal capacity is restored to persons with disabilities on an equal basis with others'. ${ }^{8}$

\section{Supported Decision-Making}

Piers Gooding states that the CRPD establishes supported decisionmaking as the 'preferred response when a person's decision-making ability is brought into question due to impairment or disability'. ${ }^{9}$ This aspect of the CRPD is connected to 'an emerging new model of legal personality and legal capacity'.

In its more radical form, this model entirely divorces legal capacity from 'mental capacity' approaches. It is grounded in the social model of disability, which views disability as resulting from the interaction between a person's individual make-up (including any 'impairment' they may have) with their social environment. The social model emphasises addressing barriers and environmental adaptations, rather than 'fixing' or 'curing' individuals. ${ }^{10}$

$6 \quad$ CPRD Art 12 .

7 See, for example, Gerard Quinn, 'Personhood and Legal Capacity: Perspectives on the Paradigm Shift of Article 12 CRPD' (Paper presented at the HPOD Conference, 20 February 2010); Australian Law Reform Commission, above n 1, [1.5], [2.2]-[2.3]; Fleur Beaupert and Linda Steele, 'Questioning Law's Capacity' (2015) 40 Alternative Law Journal 161, 161.

8 Committee on the Rights of Persons with Disabilities (UNCRPD), General Comment No 1: Article 12: Equal Recognition before the Law, 11th sess, UN Doc CRPD/C/GC/1 (11 April 2014) [7].

9 Piers Gooding, 'Supported Decision-Making: A Rights-Based Disability Concept and Its Implications for Mental Health Law' (2013) 20 Psychiatry, Psychology and Law 431, 431.

10 Lucy Series, 'Relationships, Autonomy and Legal Capacity: Mental Capacity and Support Paradigms' (2015) 40 International Journal of Law and Psychiatry 80,80 . The social model is usually contrasted with a 'medical model' that uses biomedical explanations, which 'locate disability within the individual, in terms of pathology': Gooding, above n 9, 431, fn 3. 
The new decision-making model calls for the provision of whatever support is necessary to ensure that disabled people are able to exercise full legal capacity on an equal basis with others, and addressing discriminatory attitudes and barriers that might limit the recognition and exercise of legal capacity by disabled persons. ${ }^{11}$ Gooding refers to supported decisionmaking as involving:

- offering a conceptual and practical alternative to substituted decision-making;

- protecting the right to autonomy with support appropriate to the individual in the context of exercising choice;

- autonomy being viewed as an inter-dependent rather than independent phenomenon;

- respecting the 'dignity of risk' balanced against access to information and support, and protections against abuse and exploitation;

- principles of equality and non-discrimination; and

- reflecting norms and developments (though contested) in international human rights law. ${ }^{12}$

The 2013-2014 ALRC inquiry, which culminated in the report Equality, Capacity and Disability in Commonwealth Laws (ALRC Report 124), essentially accepted the CRPD approach as the starting point for its law reform recommendations. ${ }^{13}$ At the same time, the ALRC recognised that there are difficult policy challenges in relation to decision-making by those who require the most support. In these 'hard cases', a person's will and preferences are difficult, or even impossible to determine and they need someone else to make decisions on their behalf. ${ }^{14}$ In these circumstances, the ALRC said that decision-making by a person's representative should be permitted. ${ }^{15}$

As discussed below, this form of 'representative' decision-making can be characterised as a departure - to a limited extent - from the CRPD approach, as interpreted by the United Nations Committee on the Rights of Persons with Disability (UNCRPD) in its General Comment on Art 12. ${ }^{16}$ The extent of the departure is a matter of contention and has the potential to slow progress towards new laws for supported decision-making. As the ALRC observed, contention over the 'hard cases' - where a person's will and preference is hard to discern directly from them - should not be a barrier to building law and legal frameworks that 'signal the paradigm shift of the CRPD towards supported decision-making in practice, as well as in form'. ${ }^{17}$

11 Series, above $\mathrm{n} 10,80$. This approach to legal personality is sometimes known as the 'support paradigm', or a paradigm of 'universal legal capacity': Ibid.

12 Gooding, above n 9, 445.

13 See Australian Law Reform Commission, above n 1, Ch 2.

14 See Ibid [2.116].

15 Ibid.

16 UNCRPD, above n 8, [7].

17 See Australian Law Reform Commission, above n 1, [2.116]. 


\section{Interpreting ARticle 12}

Article 12 was one of the 'most contentiously negotiated articles' in the CRPD; its controversial nature also evidenced by the high number of reservations, understandings and declarations that have been lodged on it. ${ }^{18}$

The UNCRPD is a body of independent experts which monitors implementation of the CRPD by the states parties. As with other international treaty bodies, the UNCRPD publishes its interpretation of the provisions of the Convention in the form of 'general comments' or 'general recommendations'. In April 2014, the UNCRPD issued its General Comment on Art 12. This was prompted by what it described as 'a general misunderstanding of the exact scope of the obligations of States Parties under Article 12'. ${ }^{19}$ The General Comment referred to a 'general failure to understand that the human rights-based model of disability implies a shift from the substitute decision-making paradigm to one that is based on supported decision-making'. ${ }^{20}$

Before the General Comment was issued, some commentators argued that, while the CRPD demands reform of guardianship law and practice, it does not require its abolition. One reason for this interpretation was that it was considered 'rather unlikely that the aim of the CRPD is to abolish an instrument of legal protection which is in use all over the world unless it explicitly states so'. ${ }^{21}$ Rather, the view was taken that the CRPD 'does not prohibit any form of substitution in decision-making, for example by a legal guardian. On the contrary, it requires the support by a legal guardian if somebody is not able to exercise his rights himself. ${ }^{2}$

In the General Comment, the UNCRPD referred to its previous statements, ${ }^{23}$ that states parties must 'review the laws allowing for guardianship and trusteeship, and take action to develop laws and policies to replace regimes of substitute decision-making by supported decisionmaking, which respects the person's autonomy, will and preferences'. ${ }^{24}$ It stated that the 'development of supported decision-making systems in parallel with the retention of substitute decision-making regimes is not sufficient to comply with Article $12{ }^{2}{ }^{25}$ What is required is 'both the

18 Anna Arstein-Kerslake and Eilionóir Flynn, 'The General Comment on Article 12 of the Convention on the Rights of Persons with Disabilities: A Roadmap for Equality before the Law' (2015) 20(4) International Journal of Human Rights $471,473$.

19 UNCRPD, above n 8, [3].

20 Ibid.

21 Volker Lipp and Julian O Winn, 'Guardianship and Autonomy: Foes or Friends' (2011) 5 Journal of International Aging Law \& Policy 41, 48.

22 Ibid 55-56.

23 In concluding observations on states parties' initial reports on compliance with Art 12: UNCRPD, above n 8, [3].

24 Ibid [26].

25 Ibid [28]. 
abolition of substitute decision-making regimes and the development of supported decision-making alternatives'. ${ }^{26}$

General Comments are not binding on the states parties, but are authoritative and can be a 'powerful influence on domestic policy debates'. ${ }^{27}$ In this case, as discussed below, various interpretations of the General Comment may present a possible barrier to reform of guardianship law - an unintended perverse effect.

One of the 'misunderstandings' alluded to by the UNCRPD can be traced to the Interpretative Declaration entered by Australia, in which Australia declared its understanding that the CRPD 'allows for fully supported or substituted decision-making arrangements, which provide for decisions to be made on behalf of a person, only where such arrangements are necessary, as a last resort and subject to safeguards'. ${ }^{28}$ The Australian Government's understanding of Art 12 was further elaborated in 2010, when it stated that:

In Australia, substituted decision-making will only be used as a measure of last resort where such arrangements are considered necessary, and are subject to safeguards ... For example, substituted decision-making may be necessary as a last resort to ensure that persons with disabilities are not denied access to proper medical treatment because of an inability to assess or communicate their needs and preferences. ${ }^{29}$

The Interpretative Declaration has been said to signal that laws enabling 'fully supported or substituted decision-making arrangements' for persons with mental impairments will remain in place in Australia, at least in the short term. ${ }^{30}$

Fleur Beaupert and Linda Steele state that the effect of the Interpretive Declaration is that 'technically it is impossible for Australia to breach Article 12 by retaining substitute decision-making'. ${ }^{31}$ This might be correct if Australia's position was stated to be a reservation, ${ }^{32}$ which excludes or modifies the legal effect of treaty provisions. However, an Interpretive Declaration simply purports to clarify the meaning or scope of treaty provisions, and outlines a state's understanding of its

26 Ibid.

27 Carney, above $\mathrm{n} 4,41$.

28 CRPD: Declarations and Reservations.

29 Australia's Initial Report under the Convention on the Rights of Persons with Disabilities, 3 December 2010, [55].

30 Bernadette McSherry and Kay Wilson, 'The Concept of Capacity in Australian Mental Health Law Reform: Going in the Wrong Direction?' (2015) 40 International Journal of Law and Psychiatry 60, 61.

31 Beaupert and Steele, above n 7, 163.

32 A reservation in international law is 'a unilateral statement, however phrased or named, made by a State, when signing, ratifying, accepting, approving or acceding to a treaty, whereby it purports to exclude or to modify the legal effect of certain provisions of the treaty in their application to that State': Vienna Convention on the Law of Treaties, 23 May 1969, 1155 UNTS 331, 8 ILM 679 (entered into force 27 January 1980) Art 2(1)(d). 
obligations, without purporting to exclude or modify its legal effects. ${ }^{33}$ This means that retaining substitute decision-making leaves Australia in breach of Art 12, at least in the view of the UNCRPD. A corollary is that progress towards disability rights - and law reform to promote better compliance with the CRPD - can and should continue regardless of the Interpretative Declaration. ${ }^{34}$

The extent of the reforms necessary to bring Australia into full compliance depends on what is meant by 'substitute decision-making'. The General Comment sought to clarify this, defining a substitute decisionmaking regime as a system where:

(i) legal capacity is removed from a person, even if this is in respect of a single decision; (ii) a substitute decision-maker can be appointed by someone other than the person concerned, and this can be done against his or her will; and (iii) any decision made by a substitute decision-maker is based on what is believed to be in the objective 'best interests' of the person concerned, as opposed to being based on the person's own will and preferences. ${ }^{35}$

The use of the word 'and' in this paragraph leaves open an interpretation that the UNCRPD does not consider any regime that provides decisions are to be based on will and preferences would constitute a substitute decision-making regime (even one that removes legal capacity and involves appointment against the will of the person concerned). However, this does not seem consistent with the tenor of the General Comment as ideally none of these indicia should be present in decision-making regimes. Reading in the word 'or' is not entirely satisfactory either, as it may rule out appointments without the agreement of the person concerned. The better interpretation of Art 12 may be that appointments of decision-makers in a situation of last resort, where the individual's will and preferences are unknowable and a decision needs to be made, are in fact permissible. ${ }^{36}$

\section{National Decision-Making Principles}

The CRPD and the General Comment served as the single most important starting point for the ALRC report and for its recommended National Principles. ${ }^{37}$ These Principles were intended as a legal policy guide for reform of Commonwealth, State and Territory laws and aimed to encour-

33 See International Law Commission, Guide to Practice on Reservations to Treaties (2011) [1.1]-[1.3]. Consistently, Art 46(1) of the CRPD states expressly that reservations 'incompatible with the object and purpose of the present Convention shall not be permitted'. Interpretative declarations are not mentioned. McSherry and Wilson note that this implies that if interpretative declarations by States Parties are incompatible with interpretations set out in General Comments and the like, such declarations should not inform law reform endeavours': McSherry and Wilson, above n 30, 61 .

34 Australian Law Reform Commission, above n 1, [2.97]-[2.99].

35 UNCRPD, above n 8, [27].

36 Arstein-Kerslake and Flynn, above n 18, 478.

37 Australian Law Reform Commission, above n 1, 11-13. 
age supported decision-making; make the appointment of representatives only a last resort; and to ensure that the will, preferences and rights of individuals direct decisions affecting their lives.

In developing its National Principles, the ALRC was well aware of the controversy about the extent to which regimes may retain features possibly interpreted as impermissible by the UNCRPD. The ALRC sought to avoid getting stalled by debate about exactly what is impermissible substitute decision-making under the CRPD, in part by avoiding reference to the term, and by advancing a 'new lexicon'. ${ }^{38}$ Rather, the Principles referred to a concept of 'representative decision-making'. Instead of engaging in arid debates about what does or does not constitute substitute decision-making, the ALRC suggested that the focus should not be on whether laws allow for the appointment of a person to act for (or with) another, but on the limits surrounding the appointment and the standard by which the person appointed is to act. ${ }^{39}$ That is, the focus should be on safeguards to ensure representative decision-making does not remove the person's ability to exercise legal capacity. ${ }^{40}$

Supported decision-making should not preclude the appointment of people to act on behalf of others, either by the person themselves (such as by an advance directive or enduring power of attorney) or through an institutional mechanism. ${ }^{41}$ A representative should, however, be under a duty to give effect to the will and preferences of the person represented. On some interpretations, such a representative might be said to be a substitute decision-maker - being a person appointed to make decisions on behalf of another - but can they necessarily be said to be engaging in substitute decision-making where decisions are made on the basis of the will and preferences of the person represented? At the risk of adding to terminological confusion, a representative who is responsible for making the decision they believe the person they represent would have made for themselves is sometimes referred to as exercising 'substituted judgment'. ${ }^{42}$ Such decisions, made by 'standing in the shoes' of the person represented, are quite different from impermissible substitute decision-making.

The four basic National Principles are:

Principle 1: The equal right to make decisions

All adults have an equal right to make decisions that affect their lives and to have those decisions respected.

\section{Principle 2: Support}

Persons who require support in decision-making must be provided with access to the support necessary for them to make, communicate and participate in decisions that affect their lives.

$38 \quad$ Ibid [4.34]-[4.38].

39 Ibid [2.101].

40 These safeguards are referred to in Art 12(4) of the CRPD.

41 Australian Law Reform Commission, above n 1, [2.101].

42 See, for example, Victorian Law Reform Commission, Guardianship, Final Report 24 (2012) xviii. 


\section{Principle 3: Will, preferences and rights}

The will, preferences and rights of persons who may require decisionmaking support must direct decisions that affect their lives.

\section{Principle 4: Safeguards}

Laws and legal frameworks must contain appropriate and effective safeguards in relation to interventions for persons who may require decision-making support, including to prevent abuse and undue influence. ${ }^{43}$

The focus of the discussion in this article is on Principle 3, which states that: 'The will, preferences and rights of persons who may require decision-making support must direct decisions that affect their lives.' The Will, Preferences and Rights Guidelines explain how decision-making may observe this principle in practice. The guidelines differentiate between supported decision-making and representative decision-making. As with supported decision-making, representative decision-making requires that the person's will and preferences be given effect. The 'hard cases' are covered by the guidance that:

(b) Where the person's current will and preferences cannot be determined, the representative must give effect to what the person would likely want, based on all the information available, including by consulting with family members, carers and other significant people in their life.

(c) If it is not possible to determine what the person would likely want, the representative must act to promote and uphold the person's human rights and act in the way least restrictive of those rights.

(d) A representative may override the person's will and preferences only where necessary to prevent harm. ${ }^{44}$

The National Principles have not been formally 'endorsed' by the Australian Government (to whom the recommendations of any ALRC inquiry are primarily directed). However, there has been some tacit endorsement. For example, the 2016 Terms of Reference for an ALRC inquiry into elder abuse require the ALRC 'have regard' to its own recommendations in ALRC Report $124 . .^{45}$

In 2015, the Senate Standing Committee on Community Affairs report on violence, abuse and neglect against people with disability recommended that the Australian Government 'consider driving a nationally consistent move away from substitute decision-making towards supported decision-making models'; and 'work with state and territory governments to consider implementing the recommendations of [ALRC Report 124], in relation to legal capacity and supported decision-making. ${ }^{46}$

More concretely, the Commonwealth has been the first jurisdiction to actually implement aspects of the National Principles in a legislative decision-making regime which regulates a national system for electronic

$43 \quad$ See Australian Law Reform Commission, above n 1, 11.

44 Ibid 12-13.

45 The Hon George Brandis QC, 'Safeguarding Older Australians' (Media Release, 24 February 2016) $2<$ https://www.alrc.gov.au/sites/default/files/pdfs/attorneygeneral_-_media_release_-_alrc_inquiry_elder_abuse.pdf $>$.

46 Senate Community Affairs References Committee, Parliament of Australia, Violence, Abuse and Neglect against People with Disability (2015) xviii. 
health information. In late 2015, the provisions of the My Health Records Act 2012 (Cth), dealing with 'authorised representatives' were amended. ${ }^{47}$ The amendments shifted the duty of authorised representatives from being required to act in the 'best interests' of an individual, to a duty to give effect to the 'will and preferences' of the individual. The Explanatory Memorandum observed that this change realises the principle that people with disability have an equal right to make decisions and to have those decisions respected, and is consistent with recommendations of ALRC Report $124 .^{48}$

While some progress has been made towards the ideals of supported decision-making in guardianship law and practice, the elaboration of the CRPD approach in the National Principles promises to add to the momentum. There was already an established momentum that the CRPD crystallised. John Chesterman observed, in 2013, that the CRPD is certainly affecting the way social policy responses are being crafted, very notably in the guardianship jurisdiction'. ${ }^{49}$ The effects could be seen at that time in the way the Victorian Law Reform Commission (VLRC) was approaching its guardianship review. ${ }^{50}$ What the National Principles have added to the legal policy development dynamic is that a Commonwealth legal policy process, after extensive consultation with affected stakeholders - including bodies representing persons with disability and public guardians and advocates - has endorsed the need for legislative change in the directions signposted by the CRPD.

If the CRPD is a 'signpost' towards 'supported decision-making', the National Principles shows the arterial routes more clearly. These arterial routes are the broad legal policies that should be followed in legislative regimes governing decision-making - so that, for example, legislation recognises the right to support, the concept of a supporter and a representative, and defines their roles and duties in the appropriate way.

The National Principles were not a detailed road map for reform of guardianship law. The essence of the implications of the Principles for guardianship law reform were summarised by the ALRC in stating that laws need to be reviewed 'to ensure, among other things, that guardianship and administration' are:

- invoked only as a last resort and after considering the availability of support to assist people in decision-making;

- as confined in scope and duration as is reasonably possible;

$47 \quad$ My Health Records Act 2012 (Cth) s 7A, inserted by the Health Legislation Amendment (eHealth) Act 2015 (Cth).

48 Explanatory Memorandum, Health Legislation Amendment (eHealth) Bill 2015 (Cth). The Explanatory Memorandum also referred to Art 12 of the CRPD.

49 John Chesterman, Responding to Violence, Abuse, Exploitation and Neglect: Improving Our Protection of At-Risk Adults (Report for the Winston Churchill Memorial Trust of Australia, 2013) 15. See also John Chesterman, 'The Review of Victoria's Guardianship Legislation: State Policy Development in an Age of Human Rights' (2010) 69 Australian Journal of Public Administration 61.

50 Victorian Law Reform Commission, above $\mathrm{n} 42$. The first clause of the VLRC Terms of Reference required it to have regard to the CRPD. 
- $\quad$ subject to accessible mechanisms for review; and

- consistent with decision-making that respects the will, preferences and rights of the individual. ${ }^{51}$

\section{Guardianship LaW Reform Initiatives}

The extensive work of the VLRC inquiry is an important point of reference. ${ }^{52}$ Centrally, the VLRC recommended the development of a supported decision-making and a co-decision-making arrangement as two alternatives to substitute decision-making by guardians. ${ }^{53}$ The duties of supporters and co-decision-makers would be to 'act honestly, diligently and in good faith' to assist (or make jointly) the decisions covered by their respective responsibilities. ${ }^{54}$ The VLRC did not recommend introducing any express obligations on supporters or co-decision makers to assist (or make jointly) decisions that reflect the will and preferences of the person. As discussed further below, introducing the will and preferences concept in legislation may be the single most important means by which long-term legal and cultural change in decision-making regimes can be pursued.

More recently, the Terms of Reference for the New South Wales Law Reform Commission (NSWLRC) review of the Guardianship Act 1987 (NSW) referred to the ALRC Report 124, and to the CRPD. The NSWLRC has stated that it has 'reached the tentative conclusion that there is scope for NSW to do more through our laws to encourage and promote supported decision-making' ${ }^{55}$

In 2016, the ACT Law Reform Advisory Council reported on reform of the Guardianship and Management of Property Act 1991 (ACT) and concluded that the National Principles 'provide a sound basis for reform of decision making laws in the ACT' ${ }^{56}$ The Council recommended that the ACT's new framework for supported decision-making provide for three forms of assisted decision-making: supported decision-making, co-decision-making and representative decision-making - the last stated as being where:

[I]t is not possible to provide sufficient support for a specific decision by a person with impaired decision making ability, any method chosen to make that decision must be representative of the will and preferences of the person with impaired decision making ability, as well as being consistent with their rights. ${ }^{57}$

51 Australian Law Reform Commission, above n 1, [10.22]. Existing guardianship and administration laws do contain some of these elements.

52 Victorian Law Reform Commission, above n 42.

53 Ibid Chs 8-9.

54 Ibid xxxix, xliii.

55 New South Wales Law Reform Commission, Review of the Guardianship Act 1987, Question Paper 2: Decision-Making Models (2016) 27-28.

56 ACT Law Reform Advisory Council, Guardianship Report (2016) 57.

57 Ibid 12. 


\section{A The Starting Point}

Before discussing some of the barriers to guardianship law reform, it is important to recognise how far Australian jurisdictions have already come. Terry Carney characterises the current Australian guardianship model as including many of 'progressive features'. ${ }^{58}$ Within the limits of current legislative provisions, public advocates and public guardians have been active in exploring applications of supported decision-making. For example, under NSW legislation, guardianship orders still, as a matter of form, effectively extinguish a person's decision-making autonomy and place 'strongest emphasis' on the concept of best interests. ${ }^{59}$ However, when appointed, the NSW Public Guardian tries to understand a represented person's needs and wants, based on current or previously expressed views: the person's 'will and preferences' ${ }^{60}$ The stated position of the NSW Public Guardian is to take steps to align their practice more closely with the principles of supported decision-making. ${ }^{61}$

These kinds of efforts, along with various State-based trials, pilots and research into supported decision-making, ${ }^{62}$ are evidence of a deep commitment to change among many of those most involved in the administration of existing guardianship systems. They show this commitment despite operating under legislative regimes that do not comply with even a restricted reading of Art 12. Carney observes that 'even reformed guardianship intrinsically and unavoidably entails taking away the autonomy and choice of the person subject to an order' because while the person affected may be consulted by a guardian about the exercise of powers 'the power itself has been transferred to the guardian, contrary to the CRPD preference (or obligation) to instead support people to make their own decisions'. ${ }^{63}$

Leaving aside this fundamental tension between guardianship, as currently conceived, and the CRPD, there are other problems presented by Australian guardianship laws, when measured against the CRPD and the National Principles.

\section{Appointment Criteria}

There are issues about the criteria for appointment. Australian guardianship laws provide that a guardian may be appointed - and legal capacity effectively superseded - where a person is considered to have impaired decision-making ability. The threshold for appointment is defined in

\footnotetext{
58 Carney, above n 4, 40.

59 Justine O’Neill, 'Decision-Making in Guardianship Contexts: From Substitution to Support' (2015) 24(1) Human Rights Defender 31.

60 Ibid.

61 Ibid.

62 See Ibid 32 fn 2.

63 Carney, above n 4, 40.
} 
various ways, ${ }^{64}$ but the tests all use a 'bright line approach'. ${ }^{65}$ That is, a person is considered either to have or not have the ability to make decisions. In the latter case, the power to make decisions may be removed from them by the granting of a guardianship order. There is limited recognition that a person may be supported to make a decision in circumstances where he or she would not otherwise be able to do so. ${ }^{66}$ At a minimum, legislation consistent with the National Principles would provide that a person should not be considered to lack the ability to make a decision if it is possible for them to make that decision with appropriate support. ${ }^{67}$

Another concern is the connection between 'disability' and impaired decision-making, a connection built into most guardianship legislation. For example, in Victoria and Tasmania, a guardian may be appointed for a person only if the person is 'a person with a disability' and 'unable by reason of the disability to make reasonable judgments'. ${ }^{68}$ In Tasmania, 'disability' for these purposes is defined to mean 'any restriction or lack (resulting from any absence, loss or abnormality of mental, psychological, physiological or anatomical structure or function) of ability to perform an activity in a normal manner' ${ }^{69}$ It is hard to reconcile this approach with the requirement to provide equal recognition of people with disabilities before the law. The focus should be on decision-making ability, and whether support is required - consistent with the approach of the National Principles - rather than on categorising the impairment.

\section{Supported Decision-Making}

This raises the need for laws to facilitate various forms of supported decision-making as an alternative to guardianship. Carney observes that Australia has been slow to legislate supported decision-making in

64 Victoria, Western Australia, Tasmania and Northern Territory: ability to 'make reasonable judgments'; NSW: 'incapable of managing his or her person' or 'not capable' of managing affairs; Queensland: 'impaired capacity'; South Australia: 'mental incapacity'; ACT: 'impaired decision making ability': See Guardianship and Administration Act 1986 (Vic) s 22; Guardianship and Administration Act 1990 (WA) ss 43(1)(b)(ii), 64(1)(a); Guardianship and Administration Act 1995 (Tas) ss 20(1)(b), 51(1)(b); Adult Guardianship Act (NT) s 3(1); Guardianship Act 1987 (NSW) ss 3, 14(1), s 25G(a); Guardianship and Administration Act 2000 (Qld) s 12, Sch 4; Guardianship and Administration Act 1993 (SA) s 3; Guardianship and Management of Property Act 1991 (ACT) ss 5, 7(1)(a), 8(1)(a).

65 Lise Barry and Susannah Sage-Jacobson, 'Human Rights, Older People and Decision Making in Australia' (2015) 9 Elder Law Review 1, 4.

66 See, however, Guardianship and Administration Act 2000 (Qld) Sch 1, General Principle 7 (Maximum participation, minimal limitations and substituted judgment).

67 As recommended by the VLRC: Victorian Law Reform Commission, above $\mathrm{n} 42$, Recommendation 27(e).

68 Guardianship and Administration Act 1986 (Vic) s 22(1)(a)-(b); Guardianship and Administration Act 1995 (Tas) s 20(1)(a)-(b). In Victoria, 'disability' is defined to mean 'intellectual impairment, mental disorder, brain injury, physical disability or dementia': Ibid s 3(1).

69 Guardianship and Administration Act 1995 (Tas) s 3 (emphasis added). 
comparison, for example, with Canada or Sweden. ${ }^{70}$ Some Australian guardianship legislation does provide encouragement for supported decision-making. ${ }^{71}$ In Victoria, power of attorney legislation provides for a 'supportive attorney' to be appointed. ${ }^{72} \mathrm{~A}$ supportive attorney is appointed by a person to 'support the person in making and giving effect to decisions'. ${ }^{73}$ Queensland legislation expressly authorises 'the exercise of power for a matter for an adult with impaired capacity ... on an informal basis by members of the adult's existing support network'. ${ }^{74}$ A decision or proposed decision of an informal decision-maker may be ratified or approved by the Queensland Civil and Administrative Tribunal (QCAT) ${ }^{75}$ If the QCAT approves or ratifies the exercise of power, the decision is 'as effective as if the power were exercised by the adult and the adult had capacity for the matter' and the informal decision-maker does not incur any liability for the exercise of power. ${ }^{76}$

\section{Best Interests}

A final focus for legislative reform concerns the duties of guardians, once appointed. In this regard, some Australian guardianship legislation remains firmly based on the concept of a guardian making decisions in the 'best interests' of the person they represent - a defining element of impermissible 'substitute decision-making' identified by the UNCRPD. ${ }^{77}$ For example, the Victorian Act states that a guardian must act in the 'best interests' of the represented person. ${ }^{78}$ The Act also provides that a guardian is acting in the best interests if the guardian acts as far as possible: as an 'advocate' for the represented person; to encourage participation in the life of the community; to 'encourage and assist' the represented person to 'become capable of caring for herself or himself and of making reasonable judgments'; and in 'consultation with the represented person, taking into account, as far as possible, the wishes of the represented person'. ${ }^{79}$ The latter provisions introduce elements of 'least restrictive' guardianship and respect for will and preferences - but the best interests rubric remains the primary consideration. ${ }^{80}$ Variations of this sort of provision exist in Western Australia, Tasmania and the Northern Territory. ${ }^{81}$ The

70 Carney, above n 4, 40.

71 See, for example, Guardianship and Administration Act 2000 (Qld) s 7(d).

72 See Powers of Attorney Act 2014 (Vic) Pt 7.

73 Ibid s 85(1).

74 Guardianship and Administration Act 2000 (Qld) s 9.

75 Ibid s 154.

76 Ibid.

77 UNCRPD, above n 8, [27].

78 Guardianship and Administration Act 1986 (Vic) s 28.

79 Ibid s 28. See also s 4(2).

$80 \quad$ PJB v Melbourne Health (2011) 39 VR 373, [18].

81 See, for example, Guardianship and Administration Act 1990 (WA) s 51; Guardianship and Administration Act 1995 (Tas) ss 6, 27; Adult Guardianship Act 1988 (NT) ss 4(1), 20. 
New South Wales legislation provides that the 'welfare and interests' of persons who have disabilities 'should be given paramount consideration' - effectively resulting in a best interests test of decision-making. ${ }^{82}$

Queensland, South Australian and ACT guardianship legislation adopts language that better aligns with the 'will, preferences and rights' test established by the National Principles. Under the Guardianship and Administration Act 2000 (Qld), a guardian must apply general principles set out in a Schedule to the Act. ${ }^{83}$ Except in relation to a guardian making a health care decision, ${ }^{84}$ the 'best interests' rubric is absent. These general principles refer to 'importance of preserving, to the greatest extent practicable, an adult's right to make his or her own decisions must be taken into account'; the need to seek and take account of the adult's 'views and wishes' and to 'the principle of substituted judgment'. ${ }^{85}$ Under the latter, a guardian must take a person's 'views and wishes' into account 'if, from the adult's previous actions, it is reasonably practicable to work out what the adult's views and wishes would be'. ${ }^{86}$ However, best interests can be seen as sneaking in the backdoor through the proviso that a decision must be 'consistent with the adult's proper care and protection'. ${ }^{87}$ Similar 'half-way house' formulations are found in South Australia and the ACT. That is, the legislation does not expressly refer to 'best interests' and gives some primacy to the wishes of the represented adult - but decisions must be consistent with the adult's 'proper care and protection' (South Australia) ${ }^{88}$ or not 'significantly adversely affect the protected person's interests' (ACT). ${ }^{89}$

\section{B A National Approach}

There have been repeated calls for a national approach to reform of Australian guardianship laws. In 2007, the House of Representatives Standing Committee on Legal and Constitutional Affairs, in its report Older People and the Law, recommended that the Australian Government encourage Commonwealth, State and Territory Attorneys-General 'to work towards the implementation of nationally consistent legislation on guardianship and administration'. ${ }^{90}$ In 2015, the Senate Standing Committee on Community Affairs report on violence, abuse and neglect against people with disability recommended that the Australian Government work with

$82 \quad$ Guardianship Act 1987 (NSW) s 4.

83 Guardianship and Administration Act 2000 (Qld) ss 11, 34, Sch 1.

84 Ibid Sch $1 \mathrm{cl} 12$.

85 Ibid Sch 1 cl 7(2), (3), (4).

86 Ibid Sch $1 \mathrm{cl} 7(4)$.

87 Ibid Sch 1 cl 7(5).

88 Guardianship and Administration Act 1993 (SA) s 5(d).

89 Guardianship and Management of Property Act 1991 (ACT) s 4(2)(a). Charmingly, the ACT legislation provides that a person cannot fall within the definition of a 'protected person' only because the person is 'eccentric': s 6A.

90 House of Representatives Standing Committee on Legal and Constitutional Affairs, Parliament of Australia, Older People and the Law (2007) [3.200]. 
State and Territory governments to create national consistency in the administration of guardianship laws to ensure (among other things) 'mandatory training on supported decision-making for guardians'. ${ }^{91}$

Another driver has been the development of the National Disability Insurance Scheme (NDIS) and, more broadly, moves in both aged care (the Commonwealth Home Support Program) and the NDIS towards individual funding packages, where the recipient of services has to be put at the centre of decisions about service provision. ${ }^{92}$ This reinforcing relationship between new forms of service delivery and decision-making works both ways: 'The reform of service delivery by offering individually tailored formal and informal decision-making support and a greater range of care and treatment options should be viewed as essential to implementing the support model envisaged by Art 12. ${ }^{, 93}$

The key policy driver is the CRPD (and the National Principles). In 2013, Chesterman observed the CRPD is 'promoting some degree of uniformity, and will continue to do so as jurisdictions review their guardianship systems'. ${ }^{94} \mathrm{He}$ also stated that the 'development of national guardianship principles would assist' ${ }^{95}$ - a gap now filled, at least in part, by the National Principles.

\section{The Challenges of Reform}

Some commentators suggest guardianship and mental health legislation should be entirely abolished, because 'their primary function is to provide for status-based substitute decision-making processes (based on status as a person with a disability), which deny the right to exercise legal capacity'. ${ }^{96}$ Nor is it sufficient, as the General Comment states, to develop supported decision-making systems in parallel with the maintenance of existing guardianship law. ${ }^{97}$ Anna Arstein-Kerslake and Eilionóir Flynn note:

This is an important instruction for states parties as they embark on the law reform process. Many jurisdictions have introduced options which can be used by persons with disabilities to receive support in the exercise of legal capacity. However, they are simultaneously retaining denials of legal capacity that discriminate against persons with disabilities, such as adult guardianship and other forms of substituted decision-making. The Canadian province of British Columbia and Sweden are two examples. This does not fulfil the requirements of Article 12.98

91 Senate Community Affairs References Committee, $\mathrm{n}$ 46, Recommendation 12.

92 The NDIS incorporates some limited elements of supported decision-making: National Disability Insurance Scheme Act 2013 (Cth) s 80(1); National Disability Insurance Scheme (Nominees) Rules 2013 (Cth) rr 3.1, 5.3, 5.8, 5.10.

93 Bernadette McSherry and Andrew Butler, 'Support for the Exercise of Legal Capacity: The Role of the Law' (2015) 22 Journal of Law and Medicine 739, 744.

94 John Chesterman, 'The Future of Adult Guardianship in Federal Australia' (2013) 66 Australian Social Work 26, 31.

95 Ibid 35.

96 Beaupert and Steele, above n 7, 165.

97 UNCRPD, above n 8, [28].

98 Arstein-Kerslake and Flynn, above n 18, 478 (citations omitted). 
Since the entry into force of the CRPD, many countries have begun to reform laws on substitute decision-making. ${ }^{99}$ Arstein-Kerslake and Flynn conclude that international developments are 'clearly trending towards the recognition of support to exercise legal capacity'. ${ }^{100}$

At the same time, no jurisdiction appears to have fully replaced substitute decision-making regimes - despite the fact that the first legislation to "provide a legal basis for supported decision-making and provide a true, legally binding alternative to guardianship or other forms of substituted decision-making' was enacted in 1996, in the Canadian province of British Columbia. ${ }^{101}$ The ALRC concluded that '[s]ome room for fully supported decision-making should remain'. This conclusion was said to be 'dictated by the reality that some people will always need decisions made for them'. ${ }^{102}$ The important question is how those decisions are made, a matter returned to below.

The most central element of reform of guardianship law would be the replacement of best interests decision-making with that based on the will, preferences and rights of the person represented, as recommended by the National Principles, and consistent with the CRPD. The fact that the National Principles, at the same time, allow for 'representative decisionmaking' where it is not possible to determine what the person would likely want, and may override the person's will and preferences where necessary to prevent 'harm', may alarm some human rights purists but is a defensible interpretation of what the treaty demands.

There is no argument that a representative should be able to be appointed with the consent of the person represented - in which case the appointment itself is the will and preference of that person. While there should be safeguards to ensure that this is truly what the person wants, any other conclusion would itself breach the CRPD's guarantee of equal recognition before the law. ${ }^{103}$ At the risk of circularity, support should be given to assist the decision to obtain this particular form of support - no question of capacity should arise.

The appointment of a representative, by a tribunal or other official mechanism, should also be permissible if the person is unable to communicate their will and preferences about relevant decisions, or a representative is needed to prevent harm - consistent with the Will, Preferences and Rights Guidelines, which provide that a representative may override the will and preferences of a person only where necessary to prevent harm. It

99 See Eilionóir Flynn and Anna Arstein-Kerslake, 'The Support Model of Legal Capacity: Fact, Fiction, or Fantasy' (2014) 32 Berkeley Journal of International Law 124, 133-137.

100 See Ibid 125.

101 Tim Stainton, 'Supported Decision-Making in Canada: Principles, Policy, and Practice' [2015] Research and Practice in Intellectual and Developmental Disabilities 1, 4, referring to Representation Agreement Act, RSBC 1996, c 405.

102 Australian Law Reform Commission, above n 1, [10.21].

103 That is, because people without impaired decision-making ability can, and do, appoint representatives under instruments such as powers of attorney. 
seems reasonable that this criterion might also apply to the appointment of the representative to make such decisions.

The National Principles may be criticised for leaving the "preventing harm' exception unelaborated, and this is one area where the precise legislative drafting will be critical. The ALRC characterised this provision as consistent with a 'human rights approach', ${ }^{104}$ and with the CRPD itself. Article 17 of the CRPD may require a representative to make a decision that protects the person's 'physical and mental integrity', notwithstanding the decision conflicts with the person's expressed will and preferences. ${ }^{105}$ This is part of the reason the ALRC adopted the rubric of 'will, preferences and rights', rather than simply 'will and preferences'. 'A qualification of this kind tests the limits of autonomy, particularly where the limitation concerns harm to oneself. Examples are seen usually in the context of mental health legislation: to save a patient's life, or to prevent a patient from seriously injuring themselves or others. ${ }^{106}$ There is a danger of any such exception allowing a slipping back into best interests representative decision-making unless carefully designed to ensure that it is used only in exceptional cases and with appropriate safeguards. Nevertheless, it should be accepted that the supported decision-making paradigm may allow for 'emergency interventions where an individual's life, well-being, or safety is at risk of serious adverse effects'. ${ }^{107}$

The real hard cases, however, are not emergency interventions where obvious harm may occur, but those where a person's 'will and preferences remain unknown after significant efforts to discover these have been made, and an outside decision-maker may be required to make a decision based on the "best interpretation" of an individual's will and preferences'. ${ }^{108}$ Carney has observed that support for people with very extensive cognitive impairment, while 'perfectly consistent' with this notion of best interpretation of will and preferences, is a form of supported decision-making which 'necessarily shades' towards substitute decision-making. ${ }^{109}$ In fact, 'supported decision-making in this form may be almost identical to optimally operating guardianship, both functionally and in terms of public perception' of the roles of the supporter cum guardian. ${ }^{110}$

The policy-making challenges involved in advancing various forms of supported decision-making have been comprehensively described

104 Australian Law Reform Commission, above n 1, [3.83].

105 Ibid.

106 Ibid.

107 See Flynn and Arstein-Kerslake, above n 99, 132.

108 Arstein-Kerslake and Flynn, above n 18, 486.

109 Carney states that this 'is a form of facilitated decision-making which necessarily shades towards proxy decision-making': Carney, above n 4, 45 .

110 Carney, above n 4, 45. See also, Terry Carney, 'Participation and Service Access Rights for People with Intellectual Disability: A Role for Law?' (2013) 38 Journal of Intellectual and Developmental Disability 59, 59-69. 
by Carney. ${ }^{111}$ In relation to complementing or replacing guardianship arrangements, there are many potential legislative models. These include those where the legal decision-making power stays with the supported person; those where the power is held jointly by the person and their supporter (so that a legally binding decision cannot be made by either party alone); and where the power is held by the supporter, including by agreement, but must be exercised according to the supported person's will and preferences. ${ }^{112}$

Laws to encourage supported decision-making may merely provide that supported decision-making should be 'respected and recognised'. This is already expressed in some Australian guardianship legislation - for example, Queensland legislation recognises that decision-making powers may be exercised by members of the adult's existing support network' ${ }^{113}$ Carney and Beaupert state that while the intent of such laws is clear, ${ }^{114}$ 'it does not follow that they will necessarily have any practical effect'. ${ }^{115}$ More importantly, in thinking about laws to complement or replace guardianship law, are those laws that provide specific recognition for a supported decision-making arrangement, as in British Columbia, the VLRC's supporter and co-decision-maker appointments, and the ACT Law Reform Advisory Council's three forms of assisted decision-making (discussed above).

The policy challenges involved in formulating new laws are many, and include ensuring that:

- more informal supported decision-making is not displaced by newly established legal arrangements - the 'net widening' effect, where the arrangements are applied to people who would not otherwise be made subject to any form of guardianship; ${ }^{116}$

- supported decision-making arrangements are accepted and understood by supporters and representatives and by third parties, like banks, businesses and others who deal with them - in particular, so that the arrangements do not come to be equated with guardianship powers; ${ }^{117}$

111 See, for example, Terry Carney and Fleur Beaupert, 'Public and Private Bricolage - Challenges Balancing Law, Services and Civil Society in Advancing CRPD Supported Decision-Making' (2013) 36 University of New South Wales Law Journal 175; Carney, above n 4; Terry Carney, 'Supporting People with Cognitive Disabilities with Decision-Making: Any Australian Law Reform Contributions?' (2015) 2 Research and Practice in Intellectual and Developmental Disabilities 6.

112 Carney and Beaupert, above n 111, 184-190.

113 Guardianship and Administration Act 2000 (Qld) s 9(2)(a).

114 Carney and Beaupert, above n 111, 186, referring to Vulnerable Persons Living with a Mental Disability Act 1996 (Manitoba) s 6(2).

115 Ibid.

116 Ibid 195.

117 For example, Lise Barry and Susannah Sage-Jacobson note that if 'sufficient safeguards concerning education and supervision of supporters are absent from legislation, supported decision making may simply become a form of surrogate guardianship': Barry and Sage-Jacobson, above n 65, 14-15. 
- there is clarity about the duties and responsibilities of supporters and representatives, and supporters, representatives and third parties are given appropriate protection against liability where they act in good faith in reliance on a supported decision-making arrangement. ${ }^{118}$

Commentators have highlighted the lack of evidence about what types of supported decision-making arrangements 'work'119 or indeed about how this should be evaluated. Supported decision-making 'warrants careful empirical research and pilot programs to guide legislative and social policy reform'. However, Australian pilot studies of different models of support are 'few in number, small in scale and unable to afford a rigorous evaluative design'. ${ }^{120}$

In 2013, Carney and Beaupert concluded that the issues at stake for people with cognitive and psychosocial disabilities and the public interest are too significant and potentially grave to be decided on the basis of the "muddling through" of bricolage, or on the basis of normative arguments alone'. ${ }^{121}$ In a later article, Carney again warns that the:

$[\mathrm{P}]$ olicy conundrums are compounded by a lack of evidence about the suitability-for-purpose or the efficacy of either legislated or informal schemes of supported decision-making, adding weight to calls to hasten slowly with implementation of the many permutations of such schemes internationally. ${ }^{122}$

A corrective to this perspective is provided by Gooding, questioning the extent of the caution warranted by this lack of evidence. ${ }^{123}$ He observes that there is also surprisingly little evaluative empirical literature on existing guardianship regimes, the conceptual basis for the 'best interests' standard, or the efficacy of other substitute decision-making mechanisms in law - such as involuntary outpatient treatment under mental health law. ${ }^{124}$

The call for 'evidence' regarding support to exercise legal capacity must be weighed against the qualitative criteria for justifying reform of substituted decision-making law and policy. Arstein-Kerslake argues that

118 See, for example, Powers of Attorney Act 2014 (Vic) s 114.

119 See Carney, above n 4, 41; Carney, above n 111, 14-15. The lack of data on the operation of existing guardianship systems may also be a handicap. Internationally, Lucy Series observes that there is only a very sparse literature on the experiences of people who are subject to guardianship and mental capacity laws: Series, above n 10, 89.

120 Carney, above n 4, 41.

121 Carney and Beaupert, above n 111, 199-200. Carney and Beaupert explain 'institutional bricolage' as 'where whatever is at hand is drawn on [by policy makers] to create hybrid legal and normative forms from otherwise incompatible or ill-fitting elements': Ibid 176.

122 Carney, above n 111, 7.

123 Piers Gooding, 'Navigating the "Flashing Amber Lights" of the Right to Legal Capacity in the United Nations Convention on the Rights of Persons with Disabilities: Responding to Major Concerns' (2015) 15 Human Rights Law Review 45, 67-69.

124 Ibid 68. 
'as a moral imperative ... equality of people with cognitive disabilities is "right", and is the proper aim of law reform processes'. She further argues that "the prima facie inequality enshrined in legislation is sufficient evidence to demonstrate a need for reform to reach equality and compliance with human rights law'. From this view it can be reasonably asked why advocates for supported decision-making regimes are being asked to 'prove' whether such a model works. ${ }^{125}$

The careful formulation of laws encouraging supported decisionmaking as a replacement for guardianship or other instruments is important. However, finer points of legislative drafting are not likely to be as important to outcomes as the availability of resources to facilitate the provision of support and effective oversight of arrangements by public bodies, such as Public Advocates.

\section{Conclusion}

The CRPD 'has an expressive function, and creates an opening for discussions that challenge deeply entrenched practices and ways of thinking about legal subjectivity'. ${ }^{26}$ Kristen Glen observes that the CRPD paradigm:

[S]ees incapacity as socially constructed, insists on the full legal capacity of every person with intellectual disabilities, and does away with substituted decision-making in favor of society's obligation to provide appropriate supports to permit everyone to make his or her own decisions. Like every emerging paradigm, this challenges our perceptions and our understanding of when, how, and even if the state may intervene in a person's life, and it has the potential to be deeply unsettling. And, unsurprisingly, it takes time. $^{127}$

Where the hard cases exist, the application of supported decision-making may be criticised as relying on a 'legal fiction'128 by suggesting that the will and preferences of a person can always be ascertained by using the 'best interpretation of will and preferences' approach. ${ }^{129}$ However, it is not unusual for the law to adopt legal fictions in the pursuit of important societal aims ${ }^{130}$ - in this case, ensuring that people with severe cognitive

125 Ibid 69, referring to Anna Arstein-Kerslake, Restoring Voice to People: Realizing the Right to Equal Recognition before the Law of People with Cognitive Disabilities (PhD Thesis, National University of Ireland, 2014).

126 Series, above n 10, 89.

127 Kristen Glen, 'Changing Paradigms: Mental Capacity, Legal Capacity, Guardianship, and Beyond' (2012) 44(1) Columbia Human Rights Law Review 93, 98.

128 Australian Law Reform Commission, above n 1, [3.77]. See Louise Harmon, 'Falling Off the Vine: Legal Fictions and the Doctrine of Substituted Judgment' (1990) 100 Yale Law Journal 1, 22.

129 UNCRPD, above $\mathrm{n}$ 8, [21].

130 Examples include the many contexts in which corporations are treated as 'natural persons'. 
impairment retain their personhood and remain central to decisionmaking, if only in the minds of those supporting them.

The trajectory of Australian guardianship law and practice has been bending towards the supported decision-making paradigm represented by the CRPD for some time. The latest law reform initiatives in Victoria, New South Wales and the ACT are explicitly driven by the perceived desirability of greater compliance with the CRPD and reference the National Principles. There is potential for more Commonwealth leadership in this arena, particularly through the operation of the NDIS. The ALRC saw amended NDIS legislation as an important model for reform of State and Territory laws, notably guardianship, and recommended that NDIS legislation be amended to replace its nominee scheme with a scheme for 'supporters' and 'representatives' consistent with the National Principles (and will and preferences decision-making). ${ }^{131}$ Unfortunately, progress on this front is slow. ${ }^{132}$

In the future, guardianship laws may be entirely replaced by laws that focus on the provision of support in decision-making for any adult who needs it, and regardless of whether this need arises because of something that can be labelled as 'disability'. ${ }^{133}$ The language of 'guardian' and 'guardianship' would be dispensed with, at least in relation to adults. However, as discussed above, there are problems in reaching beyond a next generation of improved Australian guardianship laws.

In the context of significant momentum towards guardianship and related law reform in a number of Australian jurisdictions, the perfect should not be the enemy of the good. That is, hopes for the complete abolition of guardianship or other forms of representative decision-making law should not act as a barrier to important advances in the wider recognition of supported decision-making mechanisms. The pragmatic way to proceed with legislative reform is to prioritise relatively simple amendments to introduce the 'will, preferences and rights' concept into guardianship law, as applicable to adults. This may also assist in advancing cultural change incrementally.

Such reforms should not have to wait until a complete scheme for supported decision-making laws is developed. ${ }^{134}$ In the context of an aging population, concerns over 'how supported decision making may be implemented and achieved in practice in Australia should not necessarily trump consideration of [measures] that could assist to prevent older people being

131 See Australian Law Reform Commission, above n 1, Ch 5.

132 For example, the COAG Disability Reform Council's 2015 draft NDIS Quality and Safeguarding Framework consultation paper made no explicit reference to encouraging supported decision-making: Disability Reform Council, Proposal for a National Disability Insurance Scheme Quality and Safeguarding Framework (2015).

133 For example, through the expansion of the roles now performed by public advocates and public guardians into a more general 'adult protection' jurisdiction: see, for example, Wendy Lacey, 'Neglectful to the Point of Cruelty? Elder Abuse and the Rights of Older Persons in Australia' (2014) 36 Sydney Law Review 99.

134 Compare Carney's admonition to 'hasten slowly': Carney, above n 4, 53. 
subjected to unnecessary control by substitute decision-makers against their will'. ${ }^{135}$

Changing the duties of guardians decisively away from the best interests model does not require complete renovation of guardianship laws. It makes sense to begin the reform process in the heart of the model, which is also where the highest levels of scrutiny and accountability for appointments and decision-making can be applied. This has the potential to make a real difference in people's lives by reorienting the culture and practice of guardianship.

135 Barry and Sage-Jacobson, above n 65, 15. 